\title{
Poverty among Women in Nigeria-Psychological and Economic Perspective: A Study Based On South West, Nigeria
}

\author{
Onwuka Ifeanyi ${ }^{1}$, Nwadiubu Anthony ${ }^{2} \&$ Isiwu Prisca $^{3}$ \\ ${ }^{1}$ Department of Banking \& Finance, University of Ibadan, Oyo State, Nigeria \\ ${ }^{2}$ Department of Banking \& Finance, Eastern Palm University, Imo State, Nigeria \\ ${ }^{3}$ Department of Psychology, Godfrey Okoye University, Enugu, Enugu State, Nigeria \\ Correspondence: Onwuka Ifeanyi, Department of Banking \& Finance, University of Ibadan, Oyo State, Nigeria. \\ E-mail: ifeanyionwuka57@gmail.com
}

Received: May 22, 2019

doi:10.5539/ijbm.v14n11p90
Accepted: September 2, 2019

Online Published: October 14, 2019

URL: https://doi.org/10.5539/ijbm.v14n11p90

\begin{abstract}
The aim of this study is to provide an evidenced-based psychological and economic perspective on the rising level of poverty among women in Nigeria. The rationale for the study is anchored on the latest reports by the World Bank and the International Monetary Fund that Nigeria is now home to the largest number of poorest people in the world. Women constitute over $60 \%$ of the poorest people in Nigeria and going by the IMF statistics that Nigeria has over 87 million people in extreme poverty translates to approximately 52 million women on the clutches of extreme poverty. Although there have been efforts by successive governments in Nigeria to improve the livelihood of women in Nigeria and lift them out from poverty, the facts on the ground are not encouraging as a large number of women continues to wallow in extreme poverty. With the benefits of inter-disciplinary research that intersects at the boundaries of finance and psychology, this study investigated possible psychological factors such as job involvement, self-efficacy and goal orientation that could be implicated in this scenario. The study used survey design in two states in South Western Nigeria namely: Lagos and Ogun. 600 women (400 in Lagos and 200 in Ogun) were sampled. The sampling was cross-sectional and respondents were selected through a multi-stage purposive sampling technique. The instrument for data collection was scaled and a step-wise multiple regression was used for testing the hypothesis. Results of the analysis showed that all the explanatory variables namely: self-efficacy, goal orientation and job involvement were significant predictors of women pre-disposition to engaging in productive activities. The result showed that women who are cognitively goal oriented strives to develop skills and are more disposed to take up productive investments (job oriented). Based on these findings, the study recommended, amongst others, that efforts should be made to re-tool the approach to women development in Nigeria through skill acquisition and value reorientation.
\end{abstract}

Keywords: Psychological perspective, Job involvement, Self-efficacy, Goal-orientation, Poverty level, Nigeria

\section{Introduction}

The recently released data from the International Monetary Fund World Economic Forum (Note 1) (2017) has once again brought to the front burner the deteriorating poverty situation, especially among women, in Nigeria. By IMF projections, Nigeria now has more people living in extreme poverty than India who hitherto hold this unenviable record. The Democratic Republic of the Congo could soon take over the number two spot. The IMF projection showed that Nigeria has about 87 million people in extreme poverty over India's 73 million. Indeed extreme poverty in Nigeria is growing by six people every minute according to the World Poverty Clock (Note 2). By extension, it is estimated that African continent will add about 3.2 million people living in extreme poverty before the end of 2018 (IMF World Economic Forum, 2017).

Moreover, according to IMF Report (2017), it is also becoming difficult to achieve the United Nations Sustainable Development Goal No. 1 (SDG1) which is ending extreme poverty by 2030. Indeed, between January 1, 2016 - when implementation of internationally agreed Sustainable Development Goals (SDGs) started — and July 2018 , the world has seen about 83 million people escape extreme poverty. But if extreme poverty were to fall to zero by 2030 , there should be a reduction in the number by about 120 million, using a linear trajectory. To get rid of this backlog of some 35 million people there is urgent need to rapidly step up the pace (IMF World Economic 
Forum (Note 3), 2017).

The global concern over the rising incidence of poverty in many low income countries served as the spark that rekindled the surge of new researches on the causative factors behind the epidemic as well as search for effective policies for reducing and ultimately, eliminating poverty (IMF World Economic Forum, 2017).

The President of Federal Republic of Nigeria (FRN), Mohammadu Buhari in his 2018 budget speech (Buhari, 2018) promised to tackle the menace of poverty. This is coming at an apt period given the fact that 2030 is around the corner when it is expected that the United Nations Sustainable Goal Number One (SDG1) of eliminating extreme would have been achieved. Moreover, the poverty situation in the country has continued to get worse by the day despite several and successive government programmes to tackle it. Poverty has simply refused to abate in Nigeria and the number of people living below the poverty line (Note 4) has continued to increase as the years go by (World Bank, 2016 and 2017).

\subsection{Statement of Problem}

The poverty scourge in Nigeria is particularly severe among women especially those in the up country, where up to 80 percent of the population continues to live below the poverty line and with limited access to social services and infrastructures (Babalola, 2008). Most of the women in up country depend on subsistence farming for food and income. They comprise the bulk of the poor groups within rural communities (Eadgerwood, 2015). By default and or culture, the men-folk are better off economically and even in terms of access to formal training and education. As a result, men have better potential to earn higher income than women generally. Again, more men are moving up to urban areas in search of greener pastures leaving more women to head families in the rural areas. This development has serious implication for poverty alleviation among women in Nigeria (Emmanuel, 2013).

It has been shown through past experiences that efforts at empowering women in Nigeria always fail because of the wrong notion that access to finance is largely what women needs to improve their wellbeing (Iheduru, 2012). This belief is perhaps, based on the age long finance-economic nexus as postulated in the early works of Bagehot during 1870s (Fowowe, 2012).

Successive governments in Nigeria have attempted to improve access to finance by women and to provide other incentives to boost women productive endeavours (Note 5). The Nigerian government even went as far as creating a special commission (Note 6) for women to demonstrate its commitment to uplifting the socio-economic status of women and eradicating extreme poverty among women. The commission was later upgraded to a full ministry dedicated entirely for women (Note 7). However, despite the lofty ideals of these programs/incentives and the large financial and material resources invested in these programmes, a large number of women still live in extreme poverty. These efforts to encourage women to participate in productive engagements; for instance, in taking up business opportunities has been largely unsuccessful. The fact still remains, that the number of women living in extreme poverty in Nigeria is huge and unacceptable. It is therefore, imperative to continue to interrogate causative factors even within the realm of psychology that pre-dispose women to the vulnerability of poverty. It is obvious that this evaluation must go beyond the usual confines of finance-growth nexus. It certainly may require an inter-disciplinary approach especially one that could intersects at the borders of finance and psychology. This study therefore, fills this need by exploring the psychological factors that could pre-dispose women favorably or unfavorably to take up productive engagements and exploit the avalanche of schemes available to them to improve their socio-economic wellbeing.

\subsection{Objectives of the Study}

The broad objective of the study is to evaluate the role psychological factors could play in pre-disposing women favourably to take up productive investments thereby improving their socio-economic wellbeing in Nigeria.

Specific objectives include:

1) To evaluate the effect of self-efficacy on women in productive investment;

2) To ascertain the effect of job involvement on women in productive engagement;

3) To identify the effect of goal orientation on women in seeking gainful employment.

\subsection{Research Questions}

The key question raised by the study was why a large number of women in Nigerian are reluctant and/or unable to take up productive engagement even in the face of various financing and entrepreneurial schemes available to them. To answer the above question, the study adopted the standard instrumentation questionnaire of Linan and Chen (2006) on Enterprise Intention Questionnaire (EIQ), VandeWalle (1997) on Goal Orientation Scale (GOS); 
Schwarzer and Jerusalem (1995) on the General Self-Efficacy (GSE) scale and Kanungo (1982) on Job Involvement (JI) Questionnaire.

\subsection{Research Hypotheses}

The following hypotheses were formulated and tested in the study:

1. Self-efficacy is a significant predictor of women's disposition in productive investment.

2. Job involvement is a significant factor to assess women's disposition to productive engagement.

3. Goal orientation is a significant variable in explaining women's disposition in seeking gainful employment in Nigeria.

\section{Review of Concepts and Literatures}

\subsection{Women and Productive Engagements - Global Overview}

It is estimated that "half of the world's population lives on less than $\$ 2$ a day, 8 million of these people live on less than $\$ 1$ a day while $70 \%$ percent of these people are women. Three hundred and forty (340) million women around the world are not expected to survive to age 40" (Thomson, 2012). It is projected that half of the workforce in the informal sector in developing countries are women (Weeks, 2011). These women make a substantial contribution to national economies (United Nations, 2016). Sadly, not many women are in the formal sector especially in developing countries.

Moreover, even the areas where women usually dominate is plagued by severe competition with very lean profit margins (United Nations, 2016).

The Global Entrepreneurship Monitor (2015) indicated that on the average, productive engagements among women across GEM countries was $8.9 \%$. In the report, it was shown that one-tenth of the women were entrepreneurs in the 37 GEM countries. Globally, women in productive employment have risen greatly. For instance, in Thailand, approximately 19 percent of women are involved in one form of productive engagement or the other. Apart from Thailand; other countries according National Women Business Council (2014) have reported larger number of women engaging in entrepreneurship.

Table 1. Status of Women's in productive engagements

\begin{tabular}{ll}
\cline { 2 - 2 } Country & Percentage (\%) \\
\cline { 2 - 3 } India & 14.1 \\
Argentina & 11.5 \\
Nigeria & 11.3 \\
Brazil & 11.1 \\
China & 11.1 \\
New Zealand & 11.0 \\
Mexico & 10.6 \\
Chile & 10.3 \\
Korea & 9.5 \\
USA & 8.1 \\
Japan & 0.6 \\
Balguim & 1.5 \\
Russia & 1.6 \\
Croatia & 1.8 \\
France & 2.1 \\
Hong Kong & 2.3 \\
Spain & 2.6 \\
Sweden & 2.6 \\
Singapore & 2.7 \\
Slovenia & 2.9 \\
\hline
\end{tabular}

Source: National Women's Business Council NWBC (2014).

The report shows that around the globe, certain factors combine to predispose women to taking up productive engagements. Some of the factors identified by NWBC (2014) include: level of education, 
culture-social-religious milieu, level of economic development, glass ceiling, etc. It should be noted that though the number of women in productive engagements around the globe has risen, there is still less number of women in productive enterprise than men. The Global Enterprise Monitor (2015) indicated that men still dominate productive enterprise in most parts of the world.

\subsection{Women Participation in Productive Engagements in Nigeria}

Women in Nigeria account for approximately half of nation's population but do not participate as much as men in entrepreneurship. Even the few that are engaged in any form of productive activity do not get credit facilities due to inhibiting cultures, beliefs and domineering influence of men. In most parts of Nigeria women are precluded from owning land. The few women who manage to start up some business have to rely on loans from money lenders who charge exorbitant rates making it almost impossible for the women to break even in their business, not to talk of making profit (Iheduru, 2012).

Although it is well known in economic literature that economic development is strengthened by women participation, denial of access to resources and other barriers - social, cultural, psychological, has somehow affected the productive activities of women and thus their contributions to economic development and growth in Nigeria.

Moreover, data from the Federal Office of Statistics showed that most of the women in productive engagements are in agriculture, manufacturing, trade and service with low profit margins and high mortality rate.

Table 2. Percentage (\%) Distribution of Persons by Industry in Nigeria

\begin{tabular}{lll}
\hline Industry & Male & Female \\
\hline Agriculture & 63.0 & 47.8 \\
Mining & 0.1 & 0.0 \\
Manufacturing & 4.0 & 3.7 \\
Utility & 1.0 & 0.0 \\
Construction & 1.0 & 0.0 \\
Trade & 12.0 & 37.6 \\
Transport & 5.0 & 0.1 \\
Finance & 0.8 & 0.3 \\
Service & 14.0 & 10.2 \\
\hline
\end{tabular}

Source: Federal Office of Statistics adopted from Community Women and Development (COWAD) 2014.

Table 2 shows that majority of the women in productive engagements are distributed into agriculture $(47.8 \%)$, trade (37.6\%), services (10.2) and manufacturing (3.7\%).

\subsection{Psychological Characteristics of Women and Productive Engagement}

Psychologically, women are unique in their characteristics and this uniqueness plays a major role among women who are engaged in productive activities. For instance, women cherish their independence. Women have greater potential for achievement and those in productive ventures have inner strength and focus. They are risk takers and have innate characteristics for intuitive thinking (Bartol \& Martin, 1998). Other characteristics that distinguish women include high level of adaptability, competitiveness, discipline, drive, honesty and organization (Buttner \& Rosen, 2012; Jaimie et al, 2013).

Moreover, women who are engaged in productive activities are motivated by a combination of psychological and socio-economic factors such as: need for achievement, desire for independence and ability to control resources (Envick\& Langford, 2000). According to Hisrich (1990), most women do not usually meet their needs with paid employment, hence, are more disposed to taking up productive activities.

\subsection{Job Involvement, Self Efficacy and Goal Orientation}

Job involvement (productive engagement) is part and parcel of life. To the psychologist, work is essential to earn a living and make contribution to the society to the society (Babalola, 2008). However, work can also inhibit an individual depending on the person's orientation and work view (Arnold, Cooper \& Robertson, 1995).

In some cultures in Nigeria, especially among the Yoruba, Ibo, Hausa, Bini, women are excluded from any paid employment and are largely expected to stay indoors and take care of domestic chores and the children. Due to these cultural barriers, many family heads will prefer their women to take up less-stressful jobs. 
Studies such as Akeredolu-Ale (2005), Olakanpo (1968), Omololu (1990) has shown the impact of psychological factors such as creative employment, self-efficacy and goal orientation on the propensity of women to take up productive engagements.

\subsubsection{Self-efficacy and Job Involvement}

Self-efficacy is defined by Sabin (1954) as a conscious and concerted effort by one to excel in whatever he/she decides to do especially in productive engagements. Self-efficacy and the role we play in productive engagements interact. It is believed that every person strives for jobs and roles that are in tandem with the self-efficacy and there is usually a conflict when there is a mix-match.

According to Fenn (1976), people with positive self-concept will go on to develop self-efficacy while the reverse will be the case. According to him, the socialization process for women focused on dependency and caring which contributes to low self-esteem. Most women have low self-esteem and as a result, may not be assertive in pursuing life-long careers. Women generally, succumb to the low standard set for them by the society and will try not to do otherwise in order not to be considered a deviant.

Women actually see themselves to be somehow inferior to men and must be subservient to the whims and caprices of the society dominated by men. To this end, her desire for higher callings like livelong career will be affected (Dipboye, 1975).

\subsubsection{Goal Orientation and Self-Efficacy}

Goal orientation is seen as an innate creative desire to do something and or to achieve a goal one set out to achieve (Allen \& Meyer, 1993). Goal orientation and commitment to self-efficacy, among other factors, might influence the desire for productive engagements. This is because an individual's goal reinforces his determination and commitment to work (Epstein, 1970). To this end, studies have shown that females put in less working time than men (e.g. Theodore, 2004). Theodore argued that this is so because women performed dual roles than then and have to allocate appropriate time for the different roles they played at home, the family and in the work place.

\section{Methodology}

\subsection{Design}

The cross-sectional survey design was adopted by the study. This was to enable the researchers acquire first-hand information from the respondents on their views on women and productive endeavours. Some of the respondents were interviewed for in-depth information that could not be captured by the structured questionnaire.

\subsection{Sample}

Six hundred women - four hundred in Lagos State and 200 in Ogun State were sampled. The sampling was multi-stage and purposive. The first stage was to create two strata of respondents - those currently engaged in productive engagement of any kind and those not engaged in any at all. The second stage involves random sampling of respondents within the strata to give all participants equal opportunity of being selected. Those who are engaged in productive engagement were sampled to find out the psychological factors that pre-disposed them favourably to take up productive investments. Those not engaged in any productive endeavours were also sampled to discover psychological factors that inhibited them from taking up productive engagements. The examination was within the explanatory variables nominated by the study, namely, self-efficacy, goal orientation and job involvement.

However, due to time constraints and for administrative convenience only, 3 local government councils in Lagos, namely Amuwo-Odofin, Oshodi-Isolo and Agege-Ifako-Ijawe were chosen for the exercise. Also in Ogun States, 4 local government councils, namely: Abeokuta North, Abeokuta South, Ado-Odo/Ota and Ewekoro were selected for the exercise.

The participants were well spread out in terms of ethnicity in Lagos area but largely Yoruba in Ogun State. The participants were within the age range of 22-60 with average age of 24. More of the women in Lagos, up to 35 percent had at least secondary education while only about 15 percent of the participants had up to secondary education in areas sampled in Ogun State.

\subsection{Instrumentation}

The questionnaire administered were structured and scaled along the three domain of interest, namely: Self Efficacy Scale, Job Involvement Scale, and Goal Orientation Scale. The instruments are defined thus: 


\section{a) Goal orientation Scale (GOS)}

The scale constructed by VandeWalle (1997) was adapted to measure goal orientation. This scale is work-specific orientation scale. The VandeWalle's scale was structured in 13-item paradigm with 3 subscales. One sub-scale has 4 items which focused on assessing performance-prove goal orientation. The second sub-scale also has 4 items focusing on performance-avoid goal orientation while the third sub-scale has 5 items focusing on learning goal orientation (VandeWalle, 1997). Respondents were required to express their opinion on each of the items in the scale on a 5-point Likert-type scale (1=strongly agree; 2=agree; 3 -undecided; $4=$ disagree; and5=strongly disagree). Internal consistency estimates were .84 for the learning goal orientation scale, .78 for the performance-prove scale and .80 for the performance-avoid scale as reported by VendeWalle.

\section{b) The General Self-Efficacy (GSE) scale}

Schwarzer and Jerusalem (1995) were credited with creating the General Self-Efficacy (GSE) scale. The scale is largely used to determine ability to contend with daily struggles as well as resilience to stressful life events. The 10 items were randomly mixed into a larger pool of items that have the same response format. As reported by Scholz, Gutiérrez-Doña, Sud, and Schwarzer (2002) in a sample of 23 countries, the Cronbach's alphas ranged from .76 to .90 . The scale is uni-dimensional, as found in a series of confirmatory factor analyses.

\section{c) Kanungo's (1982) job involvement scale (JIS)}

Kanungo's (1982) 10-item job involvement scale was used by the study. This scale measures job involvement on a five-point Likert scale with responses ranging from "Strongly disagree" (1) to "Strongly agree"(5).

\subsection{Administration Procedure}

The questionnaires were administered to the respondents in the different locations in Lagos and Ogun State using two research assistants in each of the localities involved. A consent letter accompanied each questionnaire and in Ogun State, the research assistants could speak the Yoruba language. So each of the items in the questionnaire was explained clearly to the respondents in the language they understand and they were also informed that the exercise was purely for academic purpose and the consent letter gives them to choice to participate or not to participate. Our of the 400 copies administered in Lagos, 365 were returned while in Ogun State, out of the 200 copies issued, 163 were returned. However, it was discovered that a total of 65 of the returned questionnaires were not properly completed and where discarded. Therefore, a total of 463 copies of the questionnaire were properly completed and were used for analysis.

\subsection{Econometric Technique}

Step wise multiple regression technique was used to analysis the data and generates the coefficients used in making inferences and testing the hypotheses.

\section{Results and Discussion}

\subsection{Data Presentation}

Table 3. Descriptive statistics

\begin{tabular}{|c|c|c|c|c|c|}
\hline & $\mathrm{N}$ & Minimum & Maximum & Mean & Std. Deviation \\
\hline Age & 463 & 1801283. & 6050619. & 2401283. & 2047205 \\
\hline Religion & 463 & 2184300 & 5220412 . & 3415183. & 3116804 \\
\hline Occupation & 463 & 4086891. & 3561214. & 1733305 . & 1051724 \\
\hline Highest education & 463 & 2033131. & 3061271 . & 1540053 & 9092427 \\
\hline Job involvement & 463 & 1817260. & 3443399 . & 5806151. & 1032797 \\
\hline Self-efficacy & 463 & 7923600. & 3578097. & 6007020 & 1032126 \\
\hline Goal orientation & 463 & 3263095. & 1379966. & 6542466. & 3138308 \\
\hline Productive engagement & 463 & 6655860 & 1901603. & 6575388 & 5716460 \\
\hline Valid N (listwise) & & & & & \\
\hline
\end{tabular}

Source: Computed by the Author, 2019.

The study looked at job involvement, self-efficacy and goal orientation as they predict women involvement in productive engagements. The average age of the women sampled was 24. Most of the respondents belong to Christian and Muslim religion and most were into trading as an occupation. The average respondents in the sample had up to secondary school education. 


\subsection{Correlation Analysis}

The correlation analysis presented in table 4 measures the relationship between the age, religion, education, job involvement, self-efficacy, goal orientation to productive engagement. The correlation in Table 4.2 shows that age was negatively and significantly related to occupation $(\mathrm{r}=-0.31, \mathrm{p}<0.05)$, but positively related to educational qualification and is asymptotically significant $(\mathrm{r}=0.17, \mathrm{p}<0.05)$. The correlation also shows that religion was negatively and significantly related to educational qualification $(\mathrm{r}=-0.15, \mathrm{p}<0.05)$. On the other hand, occupation was positively and significantly related to educational qualification $(\mathrm{r}=0.16, \mathrm{p}<0.01)$. Higher educational level was positively and significantly related to age, religion and occupation. Moreover, the correlation shows that job orientation was positively and significantly related to self-efficacy $(r=0.17, p<0.05)$; positively and significantly related to goal orientation $(\mathrm{r}=0.18, \mathrm{p}<0.05)$ and productive engagements $(\mathrm{r}=0.34$, $\mathrm{p}<0.01)$. Self-efficacy was positively and significantly related to productive engagements $(\mathrm{r}=0.16, \mathrm{p}<0.01)$.

From table 4, the regression coefficient showed that self-efficacy $(\beta=0.11, t=2.65, p<0.01)$ was positive and significant predictor of women's participation in productive engagement. Job involvement which entered in the regression in the first step was positive and significant $(\beta=0.74, \mathrm{t}=16.86, \mathrm{p}<0.00)$ in predicting women's involvement in productive enterprise. Goal orientation was also positive and significant in predicting women's disposition in taking up productive engagements $(\beta 0.15, \mathrm{t}=3.56, \mathrm{p}<0.01)$. This implies that the explanatory variables self-efficacy, job involvement and goal orientation entered at different steps, were jointly responsible in predicting women's psychological disposition in taking up productive engagements. These results were achieved after controlling for demographic variables (age, religion, occupation and higher educational qualification).

Table 4. Table of correlation across variables of interest

\begin{tabular}{|c|c|c|c|c|c|c|c|c|c|}
\hline \multicolumn{2}{|c|}{ Variables } & \multirow{2}{*}{$\begin{array}{l}1 \\
-\end{array}$} & \multirow[t]{2}{*}{2} & \multirow[t]{2}{*}{3} & \multirow[t]{2}{*}{4} & \multirow[t]{2}{*}{5} & \multirow[t]{2}{*}{6} & \multirow[t]{2}{*}{7} & \multirow[t]{2}{*}{8} \\
\hline 1 & Productive engage & & & & & & & & \\
\hline 2 & Age & .22 & - & & & & & & \\
\hline 3 & Religion & .06 & -.15 & - & & & & & \\
\hline 4 & Occupation & .03 & $-.31 * *$ & .05 & - & & & & \\
\hline 5 & Highest Education & .02 & $.17^{*}$ & $-.15^{*}$ & $-.15 * * *$ & - & & & \\
\hline 6 & Job Involvement & .03 & .02 & -.02 & -.04 & -.04 & - & & \\
\hline 7 & Self-Efficacy & $.16^{*}$ & .12 & -.03 & -.12 & -.03 & $.17^{*}$ & - & \\
\hline 8 & Goal Orientation & -.02 & .16 & .02 & .04 & .02 & $.18 *$ & -.01 & - \\
\hline
\end{tabular}

Table 5. Stepwise multiple regression predicting women disposition to productive engagement from job involvement, self-efficacy and goal orientation

\begin{tabular}{|c|c|c|c|c|c|c|}
\hline & $\mathbf{R}$ & $\mathbf{R}^{2}$ & $\mathbf{R}^{2} \Delta$ & B & $\operatorname{Beta}(\beta)$ & $\mathbf{T}$ \\
\hline Step 1 & .20 & .17 & .17 & & & \\
\hline Age & & & & .08 & .06 & .73 \\
\hline Religion & & & & 2.01 & .07 & .68 \\
\hline Occupation & & & & .05 & .03 & .16 \\
\hline Highest Education & & & & .25 & .31 & .69 \\
\hline Step 2 & .22 & .20 & .18 & & & \\
\hline Job Involvement & & & & .06 & .06 & .53 \\
\hline Step 3 & .24 & .22 & .17 & & & \\
\hline Self-Efficacy & & & & .20 & .21 & .25 \\
\hline Step 4 & .28 & .26 & .20 & & & \\
\hline ientation & & & & .19 & .24 & -60 \\
\hline
\end{tabular}

\subsection{Discussion of Findings}

The study looked at the increasing level of poverty among women and interrogated the role of psychological factors in predisposing women to take up productive engagements to improve their means of livelihood. The result of the analysis showed that self-efficacy was positive and statistically significant predictor of women's disposition in taking up productive engagements. Therefore, the first hypothesis which states that self-efficacy as 
a psychological factor is a significant predictor of women's disposition in taking up productive investment is confirmed. This result is line with findings of earlier studies such as Ekpe and Mat (2012). Also, Eythorsdottir (2008) reported similar results in his study. The findings of the study showed that women will favourably disposed to productive engagements like entrepreneurship when they have high self-efficacy and self-worth which appears to be correlated.

The study also showed that job involvement is a significant predictor to women's disposition to take up productive engagement. Again, the second hypothesis that job involvement is a significant factor to assess women's disposition to productive engagement is also proved. This indicates that the degree of cognitive commitment of women could influence their desire to take up productive engagements. This result is at variance with earlier studies - Eythorsdottir (2018) who found that job involvement does not influence entrepreneurial intention among female entrepreneurs in Iceland. This could be due to the larger sample size employed and the more diverse and cosmopolitan nature of the States especially, Lagos, used in the present study.

The study further revealed that goal orientation as a psychological factor is a significant variable in explaining women's disposition in seeking gainful employment in Nigeria. The resultant coefficient for this variable is positive and statistically significant. Therefore, goal orientation is a significant variable in explaining women's disposition in seeking gainful employment in Nigeria is also confirmed. This implies that women who are cognitively goal oriented are more likely to seek out productive engagements to achieve their aspirations.

\section{4 Implication of the Study and Recommendation}

The result of this study has both practical and policy implications:

a) First, it has shown that women who are self-efficacious are favourably disposed to take up productive engagements which will improve their means of livelihood.

b) Again, women who are goal oriented will strive to develop high self-efficacy which will put them in better standing in taking up productive engagements. It is unlikely that women who are not goal oriented will ever aim to be self-efficient or job involved.

c) Furthermore, in an increasingly competitive world of business, especially in developing countries where women are already disadvantaged due to culture and other barriers, it will be a herculean task for women who are not goal oriented and self-efficient to ever get a foothold in productive engagements.

Based on these findings, it is recommended as follows:

a) There is need for policy rethinking and re-tooling by government at all levels and development partners. It has been erroneously assumed that access to funding/finance is the panacea to women's participation in productive investments especially in entrepreneurship. However, the study has shown that providing funding alone is not a sufficient condition to get women into the bandwagon of productive engagement. There are other factors that need to be considered especially the psychological factors that predispose or hinder women from taking up entrepreneurship activities.

b) There is need to encourage women training in life-long skills that will make them self-efficient. To this end, there is need to revitalize the several moribund skill acquisition centres in the country that were built for skill acquisition for women. There is also the need to build more training centres for women across the country. Non-government organizations, civil society groups and development partners should be involved in encouraging women to learn productive skills for fruitful engagement in entrepreneurship.

c) There is also need for cultural re-orientation to remove all negative stereotyping of women as kitchen keepers and to encourage them to be ambitious and goal oriented like the men folks. By so doing, they will develop self-confidence, set goals, and aspire to achieve their goals through conscious efforts at self-development and ultimately be more favourably disposed to take up productive engagements and improve their means of livelihood.

\section{Conclusion}

It could be concluded that re-orientating women to develop cognitive learning goals, building self-efficacy and being job oriented will more likely pre-dispose women favorably to take up productive engagements, enhance their means of livelihood and reduce the level of poverty among women in Nigeria. This calls for re-focusing and re-tooling the approach to women empowerment from providing finance to trainings in skill acquisition and value re-orientation. 


\section{Limitation}

The study used a survey method. This might impinge on the findings from enjoying universal applicability. Surveys are based on respondents' intuition and thinking and these could be influenced by many variables which are not consistent in time and space. As such, the findings of this study may not be generalized.

\section{Recommendations for Further Research}

There is need to validate the findings of this study, perhaps, in a cross-country study. An assessment of psychological factors that predispose women to entrepreneurship in selected Sub-Saharan Africa is therefore, recommended for further research.

\section{References}

Adepelumi, P. A. (2011). Women Entrepreneurship as a tool for Economic Development in Nigeria. African Centre for Advocacy and Human Development (ACAHD)

Akeredolu-Ale, E. O. (2005). The Underdevelopment of Indigenous Entrepreneurship in Nigeria. Ibadan: Ibadan University Press.

Allen, N. J., \&Meyer, J. P. (1993) Commitment to organizations and occupations: extension and test of a three-component conceptualization. Journal of Applied Psychology, 78, 538-551. https://doi.org/10.1037/0021-9010.78.4.538

Arnold, J., Cooper, C. L., \& Robertson, I. T. (1995). Work psychology: Understanding human behavior in the workplace. London: Pitman Publishing.

Babalola, S. S. (1998). Psychosocial determinants of self-employment behavior and perceived business success. An unpublished Ph.D Thesis in Department of Psychology, University of Ibadan, Ibadan.

Babalola, S. S. (2008). Women entrepreneurial innovative behavior: The role of psychological capital. International Journal of Business Management, 4(11), 45-76. https://doi.org/10.5539/ijbm.v4n11p184

Bartol, K. M., \& Martin, D. (1998). Management. International Edition, Irwin, New York McGraw-Hill.

Buhari, M. (2018). "2018 Appropriation Bill” Being Text of Budget Speech Presented to the Joint Session of the National Assembly.

Buttner, E. H., \& Rosen, B. (1989). Funding New Business Ventures: Are Decision Makers Biased Against Women? Journal of Business Venturing, 4, 249-261. https://doi.org/10.1016/0883-9026(89)90015-3

Dipboye, R. K. (1975). Women as managers: Stereotype and realities in survey of business, Pp. 22-26.

Ekpe, I., \& Mat, N. (2012). The moderating effect of social environment on the relationship between entrepreneurial orientation and entrepreneurial intention of female students of Nigerian universities. International Journal of Management and Business Research, 1(4), 1-16.

Emmanuel, C. L. (2013). Entrepreneurship, A Conceptual Approach (2nd ed.). Pumark Nigeria Limited: 353-358. https://doi.org/10.1086/224849

Envick, B. R., \& Langford, M. (2000). The Five-Factor Model of Personality: Assessing Entrepreneurs and Managers. Academy of Entrepreneurship Journal, 6(1), 23-42.

Epstein, C. F. (1970). Encountering the male establishment sex limits on women's careers. In Anthena Theodore (Ed.), The Professional Women: Trends and Prospect.

Eythorsdottir, I. D. (2008). The Iceland female entrepreneurs: effects of entrepreneurial self - efficacy on growth intention and the influence of human capital on the formation of entrepreneurial self - efficacy. Arhus school of Business, Arhus University.

Fowowe, B. (2012). Developing Quantifiable Measures of Financial Liberalisation in Nigeria. In O. Olaniyan, A. O. Lawanson, \& B. Alayande (Eds.), Financial Sector Issues and Economic Development in Nigeria: Essays in Honour of Professor Adedoyin Soyibo (pp. 27-48).

Gatewood, E. J. (2004). Entrepreneurial Expectancies. In W. B. Gartner, K. G. Shaver, N. M. Carter, \& P. D. Reynolds (Eds.), Handbook of entrepreneurial dynamics: The process of business creation (pp. 153-162). Thousand Oaks, CA: Sage Publications. https://doi.org/10.4135/9781452204543.n13

Global Entrepreneurship Monitor. (2012). GEM Global Report. Retrieved from http://www.gemconsortium.org

Global Entrepreneurship Monitor. (2015). Women's special report. Retrieved from http://www.ogemorg.bg/reports/sp 
Hisrich, R. D. (1990). Entrepreneurship/Intrapreneurship. American Psychologist, 45(2), $209-222$. https://doi.org/10.1037/0003-066X.45.2.209

Iheduru, N. G. (2012). Women Entrepreneurship and Development: The Gendering of Microfinance in Nigeria. A paper Presented at the 8th International Interdisciplinary Congress on at Makeree University, Kampala-Uganda Women, 21-26 July.

International Monetary Fund. (2017). World Economic Outlook-Seeking Sustainable Growth Short-Term Recovery, Long-Term Challenges. https://doi.org/10.5089/9781484328095.081

Izquierdo, E. (2013). Entrepreneurial intention among university students: Motivation and entrepreneurial exposure as drives of intentions. Paper Presented at the 2013 Business Association of Latin American Studies (BALAS) conference.

Jaimie, S, P., Sullivan, C., Halbrendt, C., \& Qingbin, W. (2013). An Exploratory Study of How Rural Female Entrepreneurs View Success. University of Vermout Publication. Retreived from http://www.sbaer.uca.edu/research/2013/ICSB/aa008.htm

Kanugo, R. N. (1982). Measurement of job and work involvement. Journal of Applied Psychology, 67(3), 341-349. https://doi.org/10.1037/0021-9010.67.3.341

Luszczynska, A., Gutiérrez Doña, B., \& Schwarzer, R. (2005). General self - efficacy in various domains of human functioning: Evidence from five countries. International Journal of Psychology, 40(1), 80-89. https://doi.org/10.1080/00207590444000041

Marshall, J. (1998). Why women leave senior management jobs. In Women in Management: A Developing Presence. London: Routledge.

National Women's Business Council (NWBC). (2014). Women's Entrepreneurship around the Globe. Retrieved from http://www.nwbc.gov/documents/Issue\%20brief-GEM.pdf

Olakanpo, O. (1968). A statistical analysis of some determinants of entrepreneurial success: A Nigeria case study, Nigeria Journal of Economics and Social Studies, 10(2), 34-45.

Omololu, O. O. (1990). Graduate self-employment: A sociological examination of entrepreneur in Lagos State, Unpublished doctoral dissertation, University of Ibadan.

Rosenblatt, A., Rurner, E. M., Patterson, A. R., \& Rottensson, C. K. (1970). Dominance of male authors. Social Work, 7, 421-430. https://doi.org/10.1177/104438947005100706

Ross, F. L., \& Lyle, J. (1978). Women in industry. Lexington, Mass: Toronto.

Sabin, T. R. (1954). Role theory. In Gardener Lindzey (Ed.), Handbook of SocialPsychology.

Scholz, U., Gutiérrez-Doña, B., Sud, S., \& Schwarzer, R. (2002). Is general self - efficacy a universal construct?: Psychometric findings from 25 countries. European Journal of Psychological Assessment, 18(3), 242-251. https://doi.org/10.1027//1015-5759.18.3.242

Schwarzer, R., \&Jerusalem, M. (1993). Generalized self-efficacy scale. In J. Weinman, S. Wright, \& M. Johnson (Ed.), Measures in Health Psychology: A User's Portfolio, Causal and control beliefs (pp. 35-37). Windsor, UK: NFER-NELSON.

Theodore, A. (2004). The professional woman: Trends and prospects. Schenkman Publishing Company.

Thomson, S. (2012). Women's Entrepreneurship Development in Micro and Small Enterprises, A case Study in the Ukraine, A Paper Presented to the School of International Training, International Studies, Organizations, and Social Justice, Geneva, Switzerland, May, 6.

United Nation. (2016). Entrepreneurship and e-Business Development for Women. United Nations Publications, United Nations Publication (pp. 1-14).

United Nations. (2017). Human Development Index Report List of countries by Human Development Index United Nations Development Programme Retrieved from http://www.en.m.wikipedia

VandeWalle, D. (1997). Development of a work domain goal orientation instrument, Educational and Psychological Measurement, 57(6), 995-1015. https://doi.org/10.1177/0013164497057006009

Week, J. (2011) Encouraging Minority Entrepreneurship President Emphasizes Minority Entrepreneurship at Urban League. Minority Enterprise Development Publications, 9(17), 56-76.

World Bank. (2016). Federal Republic of Nigeria - Poverty Work Program, Poverty Reduction in Nigeria, World 
Bank, Washington D.C.

World Bank. (2017). Federal Republic of Nigeria-Poverty Reduction in the Last Decade, World Bank, Washington D.C.

World Poverty Clock. (2018). Real Time Poverty Escape Rate. Retrieved from http://worldpovertyclock@worlddata.io

\section{Notes}

Note 1. The IMF World Economic Outlook provides projections on country economic growth and poverty levels. These projections form the basic building blocks for the poverty trajectories computed for 188 countries and territories, developed and developing, across the world.

Note 2. The World Poverty Clock provides real-time poverty estimates until 2030 for almost every country. It monitors progress against Ending Extreme Poverty, which is the UN's first Sustainable Development Goal (SDG1). The escape rate calculates the current rate of poverty reduction in the world. As at $24^{\text {th }}$ July, 2018, the global poverty escape rate was 1.1 percent as against the target rate of 1.6 percent. As at that date, 87.3 million or approximately 44.2 percent of Nigeria's total population of 197.1 million live in extreme poverty.

Note 3. The IMF World Economic Outlook provides projections on country economic growth and poverty levels. These projections form the basic building blocks for the poverty trajectories computed for 188 countries and territories, developed and developing, across the world.

Note 4. The poverty line represents the value of basic needs (food and non-food) considered essential for meeting the minimum socially acceptable standard of living within a given society (UNDP, 2006). The National Poverty Rate is the percentage of a population of a country living below the poverty line. In Nigeria, the number of people living below the poverty line is 65 million as at 2016 . That represents $67 \%$ of the country's population based on 2006 population census and 2.8\% growth rate (World Bank, 2016).

Note 5. Some of these incentives date as far back as the oil boom era of 1970s spanning through the current regime. These include, but not limited to: Operation Feed the Nation (OFN), Better Life for Rural Women Program (BLP), Family Support Programme (FSP), and Family Economic Advancement Programme (FEAP) and ex-President Obasanjo's programme on National Poverty Eradication Programme (NAPEP) in 2001 with a start -up grant of six billion naira.

Note 6. The National Commission for Women (NCW) was established in 1990 to enhance Nigerian women status in entrepreneurship by addressing pertinent challenges deterring their participation in the developmental process of the economy and ensuring that women engage in creative entrepreneurship in cottage and small scale industries. The commission was also established to encourage women participation in cooperative society in urban and rural area (Adepelumi, 2011).

Note 7. Following the inauguration of democratic governance, a separate Ministry of Women and Social Development was established in 1999 to promote and coordinate issues surrounding the welfare of women in line with international standard, among other mandates. It was establish to assist in policy formulation and implementation (local and international) in the course of women development, in-line with their changing role in contemporary society (Emmanuel, 2013).

\section{Copyrights}

Copyright for this article is retained by the author(s), with first publication rights granted to the journal.

This is an open-access article distributed under the terms and conditions of the Creative Commons Attribution license (http://creativecommons.org/licenses/by/4.0/). 